\title{
HUKUM MODAL VENTURA DI INDONESIA
}

\author{
Edy Nurcahyo \\ Program Studi Ilmu Hukum, Fakultas Hukum \\ Universitas Muhammadiyah Buton \\ E-mail: cahyonur3dy@gmail.com
}

\begin{abstract}
Abstrak
Tujuan penulisan artikel hukum ini adalah untuk mengetahui perkembangan hukum modal ventura pasca terbentuknya lembaga Otoritas Jasa Keuangan (OJK), mengingat lembaga tersebut telah banyak mengeluarkan regulasi dilingkup lembaga pembiayaan termasuk pembiayaan modal ventura. Peran hukum sangatlah penting bagi pertumbuhan bisnis di Indonesia. Hukum sangat berperan untuk mengatur bisnis agar bisnis dapat berjalan dengan lancar dan tertib, sehingga terdapat kepastian hukum agar tidak ada pihak yang dirugikan akibat adanya kegiatan bisnis tersebut. Demikian pula dalam usaha modal ventura membutuhkan pembaharuan hukum sebagai sarana merespon pesatnya perkembangan bisnis menuju kearah globalisasi ekonomi.
\end{abstract}

\section{Pendahuluan}

Keberadaan usaha modal ventura di Indonesia tidak kalah pentingya dengan keberadaan lembaga perbankan, karena usaha modal ventura memiliki peluang untuk semakin berkembang dan memberikan manfaat yang besar bagi pertumbuhan ekonomi di Indonesia khususnya kepada pelaku usaha yang membutuhkan tambahan dana untuk memajukan usahanya.

Serangkaian kebijakan dikeluarkan oleh pemerintah melalui regulasi turut mendorong perkembangan usaha modal ventura di Indonesia. Dalam artikel ini akan diuraikan tentang pemahaman dasal mengenai pembiayaan modal ventura termasuk pengertian, pengaturan, manfaat, tujuan, karakteristik dari usaha modal ventura.

Melalui penyajian materi tersebut, diharapkan menjadi pemahaman dasar tentang usaha modal ventura sebagai landasan pengembangan keilmuan khususnya hukum bisnis. 


\section{Pengertian Usaha Modal Ventura}

Definis Modal Ventura (Venture Capital) menurut Tony Lorenz dan Clinton Richadson, menurut Tony Lorenz, modal ventura adalah investasi jangka panjang dalam bentuk pemberian modal yang mengandung resiko dimana penyedia dana (venture capitalis) terutama mengharapkan capital gain bukan pendapatan bunga atau deviden. Sedangkan menurut Clinton Ricardson, modal ventura adalah dana yang diinvestasikan pada perusahaan atau individu yang memiliki risiko tinggi ${ }^{1}$.

Definisi modal ventura menurut Robert White, modal ventura adalah bisnis pembiayaan untuk memungkinkan pembentukan dan pengembangan usaha-usaha baru di bidang teknologi dan/atau nonteknologi. Menurut Handowo Dipo, modal ventura dapat diartikan dana usaha dalam bentuk saham atau pinjaman yang dapat dialihkan menjadi saham ${ }^{2}$.

Menurut Keputusan Presiden Nomor 61 Tahun 1988 tentang Lembaga Pembiayaan, Perusahaan Modal Ventura adalah (Venture capital Company) adalah badan usaha yang melakukan kegiatan pembiayaan dalam bentuk penyertaan modal ke dalam suatu Perusahaan Pasangan Usaha (investee company) untuk jangka waktu tertentu ${ }^{3}$.

Dalam Peraturan Otoritas Jasa Keuangan (OJK), yang dimaksud dengan Usaha Modal Ventura adalah usaha pembiayaan melalui penyertaan modal dan/atau pembiayaan untuk jangka waktu tertentu dalam rangka pengembangan usaha pasangan usaha atau debitur ${ }^{4}$.

\section{Pengertian Usaha Modal Ventura Syariah}

Usaha Modal Ventura Syariah adalah usaha pembiayaan melalui kegiatan investasi dan/atau pelayanan jasa yang dilakukan dalam jangka waktu tertentu dalam rangka pengembangan usaha pasangan usaha yang dilaksanakan berdasarkan prinsip syariah ${ }^{5}$.

Penyelenggaraan kegiatan usaha Perusahaan Modal Ventura Syariah (PMVS) wajib memenuhi prinsip keadilan ('adl), keseimbangan (tawazun), kemaslahatan (maslahah), dan universalisme (alamiyah).

\footnotetext{
${ }^{1}$ Sunaryo, 2008, Hukum Lembaga Pembiayaan, Jakarta: Sinar Grafika, hal 19

2 Ibid, hal 19

3 Pasal 1 angka 11 Keputusan Presiden Nomor 61 Tahun 1988 Tentang Lembaga Pembiayaan

${ }^{4}$ Pasal 1 angka 1 Peraturan Otoritas Jasa Keuangan Nomor 35 /POJK.05/2015 Tentang Penyelenggaraan Usaha Perusahaan Modal Ventura

${ }^{5}$ Pasal 1 angka 3 Peraturan Otoritas Jasa Keuangan Nomor 35 /POJK.05/2015 Tentang Penyelenggaraan Usaha Perusahaan Modal Ventura
} 
Keempat prinsip syariah tersebut dijelaskan sebagai berikut:

(1) Keadilan ('adl) adalah menempatkan sesuatu hanya pada tempatnya, dan memberikan sesuatu hanya pada yang berhak serta memperlakukan sesuatu sesuai posisinya.

(2) Keseimbangan (tawazun) adalah meliputi keseimbangan aspek material dan spiritual, aspek privat dan publik, sektor keuangan dan sektor riil, bisnis dan sosial, dan keseimbangan aspek pemanfaatan dan kelestarian.

(3) Kemaslahatan (maslahah) adalah merupakan segala bentuk kebaikan yang berdimensi duniawi dan ukhrawi, material dan spiritual serta individual dan kolektif serta harus memenuhi 3 (tiga) unsure yakni kepatuhan syariah (halal), bermanfaat dan membawa kebaikan (thoyib) dalam semua aspek secara keseluruhan yang tidak menimbulkan kemudaratan.

(4) Universalisme (alamiyah) adalah dapat dilakukan oleh, dengan, dan untuk semua pihak yag berkepentingan (stakeholder) tanpa membedakan suku, agama, ras dan golongan, sesuai dengan semngat kerahmatan semesta (rahmatan lil alamin) ${ }^{6}$.

Penyelenggaraan kegiatan usaha Perusahaan Modal Ventura Syariah tidak boleh mengandung gharar, maysir, riba, zhulm, risywah, dan objek haram. Penjelasan dari larangan tersebut adalah sebagai berikut:

(1) Gharar adalah transaksi yang objeknya tidak jelas, tidak dimiliki, tidak diketahui keberadaannya, atau tidak dapat diserahkan pada saat transaksi dilakukan kecuali diatur lain dalam syariah.

(2) Maysir adalah transaksi yang bersifat spekulatif (untung-untungan) yang tidak terkait langsung dengan produktifitas di sektor riil

(3) Riba adalah pemastian penambahan pendapatan secara tidak sah (bathil) antara lain dalam transaksi pertukaran barang sejenis yang tidak sama kualitas, kuantitas, dan waktu penyerahan $(f a d h l)$, atau dalam transaksi pinjam-meminjam yang mempersyaratkan nasabah penerima fasilitas mengembalikan dana yang diterima melebihi pokok pinjaman karena berjalannya waktu (nasiah).

(4) Zhulm adalah transaksi yang menimbulkan ketidakadilan bagi pihak lainnya

(5) Risywah adalah tindakan suap dalam bentuk uang, fasilitas, atau bentuk lainnya yang melanggar hukum sebagai upaya mendapatkan fasilitas atau kemudahan dalam suatu transaksi.

\footnotetext{
6 Penjelasan Pasal 5 Peraturan Otoritas Jasa Keuangan Nomor 35 /POJK.05/2015 Tentang Penyelenggaraan Usaha Perusahaan Modal Ventura
} 
(6) Objek haram adalah suatu barang atau jasa yang diharamkan oleh syariah ${ }^{7}$.

\section{Pengertian Perusahaan Modal Ventura}

Perusahaan Modal Ventura (PMV) adalah badan usaha yang melakukan kegiatan Usaha Modal Ventura, pengelolaan dana ventura, kegiatan jsa berbasis fee, dan kegiatan usaha lain dengan persetujuan Otoritas Jasa Keuangan (OJS) ${ }^{8}$.

\section{Pengertian Perusahaan Modal Ventura Syariah}

Perusahaan Modal Ventura Syariah (PMVS) adalah badan usaha yang melakukan kegiatan Usaha Modal Ventura Syariah, pengelolaan dana ventura, dan kegiatan usaha lain dengan persetujuan Otoritas Jasa Keuangan yang seluruhnya dilaksanakan berdasarkan prinsip syariah $^{9}$.

\section{Para Pihak dalam Bisnis Modal Ventura}

Dalam setiap usaha modal ventura terlibat para pihak sebagai berikut:

1. Perusahaan Modal Ventura (PMV) atau Perusahaan Modal Ventura Syariah (PMVS)

2. Perusahaan Pasangan Usaha atau Debitur

\section{Bentuk Badan Usaha dari PMV atau PMVS}

Bentuk Badan Usaha dari Perusahaan Modal Ventura atau Perusahan Modal Ventura Syariah (PMVS) dapat berupa:

1) Perseroan Terbatas

2) Koperasi

3) Perseroan Komanditer

\section{Bentuk Pasangan Usaha}

Pasangan Usaha dapat berupa orang perseorangan atau perusahaan termasuk usaha mikro, kecil, menengah, dan koperasi yang menerima pembiayaan usaha produktif dari Perusahaan Modal Ventura (PMV)

\footnotetext{
${ }^{7}$ Penjelasan Pasal 5 Peraturan Otoritas Jasa Keuangan Nomor 35 /POJK.05/2015 Tentang Penyelenggaraan Usaha Perusahaan Modal Ventura

${ }^{8}$ Pasal 1 angka 2 Peraturan Otoritas Jasa Keuangan Nomor 35 /POJK.05/2015 Tentang Penyelenggaraan Usaha Perusahaan Modal Ventura

${ }^{9}$ Pasal 1 angka 4 Peraturan Otoritas Jasa Keuangan Nomor 35 /POJK.05/2015 Tentang Penyelenggaraan Usaha Perusahaan Modal Ventura
} 


\section{Pengaturan Modal Ventura}

Usaha modal ventura baru ada setelah diterbitkannya Keppres Nomor 61 Tahun 1988 tentang Lembaga Pembiayaan, dan Keputusan Menteri keuangan Nomor 1251 /KMK.013/1988 tentang Ketentuan dan Tata Cara Pelaksanaan Lembaga Pembiayaan. Kedua peraturan ini menjadi penanda awal berkembangnya hukum modal ventura ${ }^{10}$.

Abdulkadir Muhammad dan Rilda Murniati, mengelompokkan sumber hukum modal ventura ke dalam dua klasifikasi, yaitu dari segi hukum perdata, dan dari segi hukum publik. Dari segi perdata, perjanjian adalah sumber utama hukum modal ventura, adapun dari segi publik adalah peraturan perundangan sebagai sumber utama dalam hukum modal ventura ${ }^{11}$.

\section{Peraturan Lembaga Pembiayaan}

Peraturan tentang lembaga pembiayaan yang mengatur usaha modal ventura dapat digolongkan menjadi dua (2), yaitu:

1. Peraturan lembaga pembiayaan yang mengatur usaha modal ventura sebelum terbentuknya lembaga Otoritas Jasa Keuangan (OJK):

(a) Peraturan Pemerintah Nomor 18 Tahun 1973

(b) Keputusan Presiden Nomor 61 Tahun 1988 Tentang Lembaga Pembiayaan

(c) Keputusan Menteri Keuangan Nomor 1251/KMK.013/1988 Tentang Ketentuan dan Tata Cara Pelaksanaan Lembaga Pembiayaan

(d) Keputusan Menteri Keuangan Nomor 468 Tahun 1995 Tentang Perubahan Keputusan Menteri keuangan Nomor 1251/KMK.013/1988 Tanggal 20 Desember 1988 Tentang Ketentuan dan Tata Cara Pelaksanaan Lembaga Pembiayaan Sebagaimana Telah Diubah Dengan Keputusan Menteri Keuangan Nomor 1256/KMK.00/1989 Tanggal 18 Nopember 1989 Menteri Keuangan Republik Indonesia

Peraturan lembaga pembiayaan yang mengatur usaha modal ventura setelah terbentuknya lembaga Otoritas Jasa Keuangan (OJK:

(a) Undang-Undang No. 21 Tahun 2011 Tentang Otoritas Jasa Keuangan

(b) Peraturan Menteri Keuangan No. 8 /PMK.010/2012 Tentang Perusahaan Modal Ventura

(c) Peraturan Otoritas Jasa Keuangan No. 1/POJK.07/2013 Tentang Perlindungan konsumen Sektor Jasa Keuangan

${ }^{10}$ Sunaryo, Op. Cit., hal 20

${ }^{11} \mathrm{Ibid}$, hal 20 
(d) Peraturan Otoritas Jasa Keuangan No. 1 /POJK.07/2014 Tentang Lembaga Alternatif Penyelesaian Sengketa di Sektor Jasa Keuangan

(e) Peraturan Otoritas Jasa Keuangan No. 35 /POJK.05/2015 Tentang Penyelenggaraan Usaha Perusahaan Modal Ventura

\section{Perjanjian Kegiatan Usaha Modal Ventura}

Seluruh perjanjian kegiatan usaha antara Perusahaan Modal Ventura (PMV), Perusahaan Modal Ventura Syariah (PMVS) dengan Pasangan Usaha (PU) atau Debitur wajib dibuat secara tertulis ${ }^{12}$.

Menurut Subekti, Perjanjian adalah suatu "peristiwa di mana seorang berjanji kepada orang lain atau di mana dua orang itu saling berjanji untuk melaksanakan suatu hal".

Perjanjian modal ventura adalah penjanjian antara Perusahaan Modal Ventura (PMV) atau Perusahaan Modal Ventura Syariah dengan Perusahaan Pasangan Usaha (PPU) dalam rangka penyaluran modal ventura.

\section{Bentuk Kegiatan Usaha Perusahaan Modal Ventura}

Perusahaan Modal Ventura (PMV) menyelenggarakan Usaha Modal Ventura dalam bentuk:

1) Penyertaan Saham (Equity Participation);

Penyertaan saham (Equity Participation) adalah penyertaan saham yang dilakukan melalui pembelian saham pada Pasangan Usaha yang belum diperdagangkan di bursa saham.

Penyertaan saham dalam ketentuan ini meliputi juga private equity.

2) Penyertaan Melalui Pembelian Obligasi Konversi (Quasi Equity Participation);

3) Pembiayaan melalui pembelian surat utang yang diterbitkan Pasangan Usaha pada tahap rintisan awal (start-up) dan/atau pengembangan usaha; dan/atau

4) Pembiayaan usaha produktif ${ }^{13}$.

\section{Bentuk Kegiatan Usaha Modal Ventura Syariah}

Perusahaan Modal Ventura Syariah (PMVS) menyelenggarakan Usaha Modal Ventura Syariah dalam bentuk:

1) Investasi, yang terdiri dari:

\footnotetext{
12 Pasal 26 ayat 1 Peraturan Otoritas Jasa Keuangan Nomor 35 /POJK.05/2015 Tentang Penyelenggaraan Usaha Perusahaan Modal Ventura

13 Pasal 2 ayat 1 Peraturan Otoritas Jasa Keuangan Nomor 35 /POJK.05/2015 Tentang Penyelenggaraan Usaha Perusahaan Modal Ventura
} 
a) penyertaan saham (equity participation);

b) Pembelian sukuk atau obligasi syariah konversi;

c) Pembelian sukuk atau obligasi syariah yang diterbitkan Pasangan Usaha pada tahap rintisan awal (start-up) dan/atau pengembangan usaha; dan/atau

d) Pembiayaan berdasarkan prinsip bagi hasil

2) Pelayanan Jasa; dan/atau

3) Kegiatan usaha lain berdasarkan persetujuan OJK

\section{Tujuan dan Manfaat Modal Ventura}

Tujuan dari usaha modal ventura tentu berorientasi pada bisnis yaitu untuk mendapatkan keuntungan yang besar. Namun bukan berarti usaha modal ventura tidak memiliki resiko yang tinggi (high risk). Selain itu, keberadaan modal ventura menjadi mitra bagi usaha yang masih lemah baik dari segi permodalan maupun manajemen usaha. Modal venura banyak memberikan manfaat bagi pengembangan usaha di Indonesia baik usaha yang dilakukan oleh badan usaha yang berbadan hukum maupun non badan hukum.

\section{Karakteristik Modal Ventura}

Beberapa karakteristik yang melekat pada usaha modal ventura adalah sebagai berikut:

1) Bantuan pembiayaan pada perusahaan pasangan usaha bukan dalam bentuk pinjaman (loan), tetapi dalam bentuk penyertaan modal (equity participation) atau setidaktidaknya pinjaman yang dapat dialihkan ke equity (convertible)

2) Bantuan pembiayaan bersifat sementara, sampai pada waktunya dilakukan divestasi

3) Penyertaan modal bersifat jangka panjang (long term)

4) Pembiayaan ini berisiko tinggi (high risk)karena tidak didukung dengan jaminan (collateral)

5) Motif utamanya adalah bisnis, yaitu mendapatkan keuntungan yang tinggi berupa capital gain sebagai imbalan atas risiko yang tinggi

6) Perusahaan modal ventura terlibat dalam manajemen (hand on management) pada perusahaan pasangan usaha

7) Investasi modal biasanya dilakukan terhadap perusahaan yang tidak punya kases untuk memperoleh kredit dari bank

8) Umumnya ditunjukkan pada perusahaan kecil atau perusahaan baru, tetapi memiliki potensi besar untuk berkembang 


\section{Divestasi}

Divestasi adalah penjualan Perusahaan Modal Ventura (PMV) atau Perusahaan Modal Ventura Syariah (PMVS) yang berada pada Pasangan Usaha yang bersangkutan. 


\section{Daftar Pustaka}

Ahmad Muliadi, 2013, Hukum Lembaga Pembiayaan, Jakarta: Akademia Permata

Burhanudin Ali SDB \& Poernama S, 2016, 5 Menit Langsung Jadi Membuat Surat Perjanjian (Surat Kontrak), Jakarta: Anugrah

Edy Nurcahyo, 2016, Perlindungan Hukum Kerjasama PT. Sarana Jateng Ventura dengan Perusahaan Pasangan Usaha dalam Pemberian Modal Ventura, Jurnal Sang Pencerah ISSN 2460-5697

Munir Fuady, 2006, Hukum Tentang Pembiayaan, Bandung: Penerbit PT. Citra Adiya Bakti

Sunaryo, 2008, Hukum Lembaga Pembiayaan, Jakarta: Sinar Grafika

Wirjono Prodjodikoro, 2000, Asas-asas Hukum Perjanjian, Bandung: Penerbit Mandar Maju Zainal Asikin, 2016, Hukum Dagang, Jakarta: PT. RajaGrafindo Persada

Peraturan Perundang-Undangan:

Peraturan Menteri Keuangan No. 8 /PMK.010/2012 Tentang Perusahaan Modal Ventura

Keputusan Menteri Keuangan No. 1251 /KMK.013/1988 Tentang Ketentuan dan Tata Cara Pelaksanaan Lembaga Pembiayaan

Peraturan Otoritas Jasa Keuangan No. 35 /POJK.05/2015 Tentang Penyelenggaraan Usaha Perusahaan Modal Ventura

Peraturan Otoritas Jasa Keuangan No. 1 /POJK.07/2014 Tentang Lembaga Alternatif Penyelesaian Sengketa di Sektor Jasa Keuangan

Peraturan Otoritas Jasa Keuangan No. 1/POJK.07/2013 Tentang Perlindungan konsumen Sektor Jasa Keuangan

Undang-Undang No. 21 Tahun 2011 Tentang Otoritas Jasa Keuangan 